\title{
EFFECTIVE KNOWLEDGE TRANSFER IN FAMILY FIRMS
}

\author{
Rosa Nelly Trevinyo-Rodríguez \\ Josep Tàpies
}




\title{
EFFECTIVE KNOWLEDGE TRANSFER IN FAMILY FIRMS
}

\author{
Rosa Nelly Trevinyo-Rodríguez' \\ Josep Tàpies ${ }^{2}$
}

\begin{abstract}
One of the most critical organizational changes that family businesses must address at some stage in their lives is the succession process. When evaluating this process, two main targets are sought: quality and effectiveness. In order to meet these quality-effectiveness standards, three elements must be transferred from the predecessor to the Next Generation Member(s): 1) Ownership/power; 2) Management responsibility, and 3) Competence/Knowledge. We focus on the third element: Knowledge, since most of the times, it is "the taken-for-granted" factor. How effective intergenerational knowledge transfer in family firms takes place - under what conditions and through which variables - is the heart of this paper. We have developed a Knowledge Transfer Model in Family Firms (KTFF) which presents several internal and external relationships in the Family-Enterprise-Next Generation System. And, although this is a conceptual text, it may drive future empirical research projects in order to provide support for the proposed interactions (relationships).
\end{abstract}

Keywords: Knowledge Transfer, Learning, Knowledge Acquisition, Family Firms, Family Business, Next Generation, Succession, EDUCATE Standard, Knowledge Transfer Model in Family Firms (KTFF).

NOTE: Published in the "Family Business Research Handbook", edited by Panikkos Poutziouris, Elgar Publishing, 2006.

\footnotetext{
${ }^{1}$ Professor, ITESM, Monterrey

${ }^{2}$ Professor of Finance, Chair of Family-Owned Business, IESE
} 


\section{EFFECTIVE KNOWLEDGE TRANSFER IN FAMILY FIRMS}

\section{Introduction}

One of the most common ways organizational changes are brought about in any business is through the replacement of key personnel. This process is generally called administrative succession. Indeed, organizationally, succession is important for two basic reasons: 1) it always leads to organizational instability, and 2) it is a phenomenon that all organizations must cope with (Grusky, 1960). One reason why all organizations must cope with the succession process is very obvious: We are all mortal beings. However, it is important to note that not all businesses face the same problems when entering the succession stage. Family firms are a special case where succession is extremely delicate, since some additional, special dimensions have to be taken into account; for instance, the family and its dynamic relationships.

Without doubt, the succession processes in family firms represent the most critical period confronting family businesses, since it is precisely when the business is transferred from one generation to the next. And of course, one of the main dreams a founder typically has is to hand down his legacy to his offspring, given that he has accumulated capital, commitment of potential members, entrepreneurial skills, and legitimacy (Stinchcombe, 1965). In addition, he has already generated learning curves (diminishing costs) and built a reputation that can provide a springboard for his family to jump and build from. In truth, he has created a high reliable and accountable business. Nevertheless, the very factors that make a system reliable and accountable (reproducible - it has the same structure today that it had yesterday) also make it resistant to change. That is precisely why succession is so crucial.

Due to the importance and inevitability of succession processes, much attention has been drawn to the need for family firms to develop formal succession plans, and to start planning the let-go stage as early as possible. In actual fact, assuming all else to be equal, the extent of organizational instability following succession tends to be inversely related to the amount of control over the process (Grusky, 1960). Thus, progress in explaining an organizational change, such as succession, requires understanding both its nature, and the degree to which it can be planned and controlled (Hannan and Freeman, 1984).

Focusing on the planning and control of organizational change, Handler (1990) affirms that when evaluating the succession process, two targets are sought: quality and effectiveness. Quality is a reflection of how the involved family members personally experience the process, 
while effectiveness is more related to how others judge the outcome of the succession. To meet these quality-effectiveness standards, three elements must be transferred between the generations: 1) ownership/power, 2) management responsibility, and 3) competence/knowledge (Varamäki, Pihkala, and Routamaa, 2003). In addition to these three elements, there are various psychological factors that may also influence the effects of the succession process, such as: the successor's (or potential candidate's) personal skills and administrative experience outside of the business, his commitment to the goals of the family and organization, and the legitimacy he has for the position in the eyes of the company's employees.

In spite of the fact that little attention has been devoted to the study of how knowledge is transferred in family businesses, most of the studies on the topic of succession usually take this transmission for granted. On the other hand, there are signs that perspectives related to knowledge transfer and learning processes are important because one sees them appearing constantly across disciplines. However, in spite of the considerable progress made in bridging disciplines, there is almost no organizational learning and/or family business literature focusing on "How effective intergenerational knowledge transfer takes place in family firms." Consequently, our intention in this study is to determine the variables and conditions that promote effective knowledge transfer in family businesses, thus bridging the organizational learning and family business areas.

How knowledge is transferred within the same firm across generations is an issue that may explain to some extent (in addition to the leadership-keeping process) why most family business do not survive to the third generation, with a much higher mortality/death rate during the owner-second generation transition. Although we will maintain a completely theoretical approach in this paper, the ultimate aim is to establish a knowledge transfer framework (with variables and conditions) that can be used later in empirical research to provide support for the relationships proposed.

This chapter is organized as follows. First, we will analyze whether knowledge transfer in family firms is different from knowledge transfer in other firms, and if so, we will proceed to examine the concept of individual learning and how it is related to knowledge acquisition and transmission. Second, we will develop a knowledge transfer model applied to family firms that describes the variables and conditions that interact during knowledge transmission processes.

\section{Is Knowledge Transfer in Family Firms Different from Knowledge Transfer in Other Firms?}

The primary roots of knowledge are the disciplines of philosophy and sociology. Writers such as Popper, Lakatos, Feyerabend, Berger, Luckmann, Polanyi, Kuhn, Wieck, and Giddens influenced the thinking on knowledge in organizational and economic life. However, despite the fact that a lot has been written on this subject, there is no ONE standard definition of knowledge. In this paper, we will use Tsoukas and Vladimirou's (2001) interpretation of knowledge - from the Organizational Learning Literature-: Knowledge is the individual capability to draw distinctions, within a domain of action, based on an appreciation of context or theory, or both; it presupposes values and beliefs, and is closely connected with action.

Knowledge is primarily "Personal:" it is mostly the property of the people who acquire and use it. In fact, it has been found that people in organizational environments are much less likely to 
share what they know with their colleagues, since they consider them "proximate competitors" in the labor market. Employees usually regard certain areas of their knowledge as part of their power base within the company; thus, their willingness to share is limited (Probst, Raub and Romhardt, 2000). Moreover, human beings are generally reluctant to communicate their own knowledge stock for reasons of self-interest and opportunism (Agency Theory). In fact, individuals would generally tend more to share their knowledge with people outside of their organization (and even with those in other organizations) than with their own colleagues... As the motto attributed to Machiavelli says, "People make wars with neighbors and alliances with far-located partners."

However, the main point here is that 'unless the implications of experience can be transferred from those who experience it to those who did not, the lessons of history are likely to be lost' (Levitt and March, 1988, p. 328). So, what do organizations do to preserve experience and transmit knowledge? Well, most of them encapsulate it in computers via databases and systems. Others implement rules and procedures that dictate how people should behave in almost every situation. On the other extreme, there are many family-owned organizations that instead of writing each single rule in an organizational memory pass on their knowledge from generation to generation by means of tradition and value systems.

Family firms have a certain advantage in the "competitive non-sharing issue," since all owning members (usually from the family) earn their living from the same source: their business. In addition, family owners and Next Generation Members tend to share the same objective or dream (assuming no family conflicts). There is also an element of trust that holds the family and the business together. And even though some authors may argue that there is no difference between a family business and a non-family firm, the fact is that personal relations are stronger within a family than in any business relationship. As Granovetter (1985) pointed out: 'Departing from pure economic motives, continuing economic relations often become overlaid with social content that carries strong expectations of trust and abstention from opportunism... [However] it would never occur to us to doubt this last point in more intimate relations, which make behavior more predictable... In the family, there is no Prisoner's Dilemma because each is confident that the other can be counted on. In business relations, the degree of confidence must be more variable' (Granovetter, 1985, p. 490-491).

It is well-known that one important factor that affects knowledge transferability is the perceived trustworthiness of the knowledge's source (Szulanski, Cappetta, and Jensen, 2004; Wathne, Roos, and Krogh, 1996). Experiments in the communication field have shown that a trustworthy source can substantially influence a recipient's behavior (Hovland et al., 1949; Allen and Stiff, 1989; Perry, 1996; Szulanski, Cappetta and Jensen, 2004). Likewise, trust develops over time as a consequence of individual interaction; ultimately, trust is deposited in a person, not in that person's specific actions (Rempel et al., 1985). In dealing with this "trust" factor, family firms tend to be ahead of non-family businesses, since owners and Next Generation Members in the former tend to be more closely related and know each other personally. The latter is much more difficult in big non-family firms where the shareholders' power is diluted and represented by board members. And even though these board members (top executives) may be connected by networks of personal relations and may be able to generate trust among their own employees and shareholders, their ties will surely not be as strong as the ones developed among family members.

The strength of the relationships between parents and children (Next Generation Members) is what Coleman (1988) called Social Capital. Thus, there is a lack of social capital in the family if 
there are no strong relationships between Next Generation Members and parents (owners). The development of social capital within the family depends on two factors: the physical presence of parents in the family (owners) and the attention given by the parents to the Next Generation Members. In this text, we assume the presence of both.

Similarly, we have to consider not only the source's trustworthiness, but also its availability and desire to transfer knowledge. In general, family business owners are inclined to teach Next Generation Members EVERYTHING THEY KNOW ABOUT THE BUSINESS, since their main dream is that their KIDS continue it and build on it. The founder wants to teach his siblings (and/or in-laws when the case applies) how to learn faster than their competitors, in order to improve the family business's chances of survival. However, in other kinds of organizations, this may not happen, first of all because of the high staff turnover; second, because of agency problems. Another factor is that a family firm's business reputation is closely linked to the family's reputation. The reason why is that the values and ideas promoted in the firm are represented by the owner(s) and his family, to the extent that the family's surname is often included in the company's name. Thus, a special consideration regarding their own reputation as individuals is attached to the family firm, making their commitment much higher and their continuation dream more vivid.

Consequently, the source's trustworthiness, time availability and desire (among other factors) enhance knowledge transfer, influencing the likelihood of behavioral change by the recipient. Furthermore, knowledge transfer is not mechanical, but interactive and embedded in existing capabilities on both sides and in the social relationships between them. Thus, without a good disposition and commitment on both sides, knowledge transfer becomes more complex and complicated. One of the obvious principles of human communication is that the idea transfer occurs most frequently between a source and a receiver who are alike, similar, homophilous (Rogers and Shoemaker, 1971). If we consider "homophily" to mean the degree to which pairs of individuals who interact are similar in certain attributes, such as beliefs, values, education, from the same family, etc., it follows that there may be a better understanding, disposition, and commitment between family members than between non-family members, since communication is easier (assuming no conflict). As the old adage goes: "Birds of a feather flock together."

Having asserted that knowledge transfer in family firms is different from knowledge transfer in non-family firms, we will proceed to analyze the individual learning process, in order to understand how knowledge is acquired, assimilated and used by Next Generation Members. To do so, we will draw from sociological, psychological and organizational theory literature.

\section{Learning and Knowledge}

"One must learn by doing the thing, for though you think you know it - you have no certainty, until you try."

Sophocles, 400 B.C.

To understand how knowledge is transferred, we must first study how individual learning takes place, since knowledge is the outcome of learning. As stated by Piaget (1968) "learning” can be defined as a continuous genesis, a process of creation and recreation where gestalts and logical structures are added or deleted from memory over time. If this is so, learning has an implicit 
assumption of change. Therefore, we may say that individual learning is dynamic and cyclic; it is a process by which relatively permanent changes occur in a person's behavior as a result of some experience or knowledge the person has acquired (Bass and Vaughn, 1966). However, learning success is based on knowledge acquisition (Polanyi, 1975), not on behavioral change, since it may rarely happen that knowledge is gained without any accompanying change in explicit behavior (Fiol and Lyles, 1985), but only in the individual's private knowledge.

When analyzing the literature on individual learning, we found a tacit agreement among the authors reviewed in that individual learning usually happens through experimentation, evaluation and assessment; it is a process rather than an outcome. Other interesting insights, such as that of March and Olsen (1975), pointed out that roles, duties and obligations were behaviorally important to involvement in the learning process, affirming that without doubt "People often make decisions because they believe they are expected to." Numerous research studies (Bower, 1981; Picard, 1997; Gadanho and Custódio, 2002; LeDoux, 1998; Underwood, 1983; Wickens and Clark, 1968) have proposed that emotional responses (affect) are a critical component of memory, representing an associative network connected to certain events, such as family actions, rituals, expectations, decisions, etc. Damasio (1994) suggested that humans associate high-level cognitive decisions (for instance, the decision to make a conscious effort to actively remember/learn what is being experienced) with special feelings (emotions) which have good or bad connotations, depending on whether choices have been emotionally associated with positive or negative long-term outcomes. Bahrick (1984), Salasoo et al. (1985) and Johnson and Hasher (1987) suggest that as the level of learning increases and new connections are made with events, some portion of this type of knowledge becomes permanent, and will be maintained indefinitely, even in the absence of further rehearsals, and regardless of potential interference encountered during the retention interval. Therefore, expectations, ideals and shared dreams connected with emotions and values are important - though not easily detected - intangible factors that influence the nature of learning.

In addition, learning (as well as adaptation) must consider the complexity of the environment relative to time, energy, uncertainty, relative importance of attainment of success versus avoidance of failure, the individual's experience or non-experience, preferences, goals and aspiration levels, incentives, etc. (Cangelosi and Dill, 1965). If the environment is too complex and dynamic for the individual to cope with it, overloading may occur, inhibiting learning and knowledge acquisition (Lawrence and Dyer, 1983). It is therefore better to learn step by step, since assimilation becomes more enduring, and errors (misleading signals produced by noise) are reduced. This view closely matches the findings obtained in some well-known psychology studies regarding individual learning, which noted among other things that:

1) Distributed learning activities seem more effective than mass learning. ("Step by Step").

2) Learning which is rewarded (positively reinforced) will tend to be repeated, remembered, and utilized in other situations. - Time is a critical factor to foster repetition.

3) Knowledge of results (feedback) enhances learning.

4) The more the learner is ready and motivated to learn, the more learning will occur.

5) Learning must be transferable to the current job and to future job situations to be of practical value.

6) For learning to be most effective, the new behaviors must be practiced. 
Applying the latter to family firms, we realize that, for Next Generation Members, previous attitudes and beliefs also form the structure for future cognition, affecting learning commitment, attitude and behavior. Undeniably, learning is influenced and determined by attitude, values, trust and commitment. The behavior shown by Next Generation Members (NGM) will depend on the relationship between the outcomes they observe and the aspirations they have for those outcomes (Levitt and March, 1988) as well as on the rewards and punishments administered. Likewise, since learning is a dynamic process that takes time (for the assimilation of knowledge, repetition and incentives need to be "a given"), predecessors should start transmitting their knowledge to NGM at early stages in life in order to achieve a more effective knowledge transfer. However, for learning to occur, a certain amount of stress is necessary (Cangelosi and Dill, 1965; Hedberg, Nystrom and Starbuck, 1976; Hedberg, 1981; Fiol, and Lyles, 1985). Thus, predecessors must create situations where NGMs can act, reflect and name their findings. "By directing their explorations and naming their observations, they begin to understand their environment and become more able to manipulate and change their situations" (Freire, 1970). Although affluence sometimes initiates searches for opportunities (Lewin and Wolf, 1975), it is usually scarcity, conflict, and substandard performances that lead to actions, while wealth, harmony and goal accomplishment breed complacency and reinforce current behaviors. Learning is typically triggered by problems (Hedberg, 1981). Thus, when thinking about transferring knowledge to NGMs, the predecessor must remember that the learning and assimilation of concepts and ideas by the NGMs will be based on the challenges they face, the constant rewards and punishments they receive (Lieberman, 1972), as well as their own actions and findings, in conjunction with the expectations they perceive and share, the values they have internalized and the commitment they show (related to their own interests and personality).

Finally, the level of stress and the degree of uncertainty about past successes will also determine the effectiveness of learning conditions, as well as how the environment is perceived and interpreted (Daft and Weck, 1984; Starbuck et al., 1978; Weick, 1979; Fiol and Lyles, 1985). And, for learning to be effective, there must be an interaction between NGMs, the predecessor and the situation. Acting, or learning by doing is the means to acquire knowledge (Freire, 1973).

'Acknowledging that all knowledge contains a personal element, or to put it differently, "[recognizing] personal participation as the universal principle of knowing" (Polanyi, 1975, p. 44), implies that knowing always is, to a greater or lesser extent, a skillful accomplishment, an art' (Tsoukas and Vladimirou, 2001, p. 982). Consequently, the learning process, or the acquisition of knowledge, will be dependent upon individual attitudes. In effect, in order to know something, the individual must act and integrate a set of details or "particulars" of which he is subsidiarily aware (unconscious). Basically, in order to make sense of his experience, the individual relies on some parts of it subsidiarily in order to attend to the main objective focally. In the real world, we comprehend something as a whole (focally) by tacitly integrating certain particulars, which are known by the actor subsidiarily (Tsoukas and Vladimirou, 2001).

The intriguing question of whether unconscious stimuli influence thought and behavior has been constantly studied in psychology (Dixon, 1971; Erdelyi, 1984, 1985; Kihlstrom, 1984; Johnson and Hasher, 1987). And important demonstrations of meaningful processing of unconscious stimuli have been reported by Marcel (1983), Fowler et al. (1981) and McCauley et al. (1980). Moreover, indirect tests do seem to reveal long-lasting consequences of unconscious processing (Johnson and Hasher, 1987). Consequently, we suggest that Next Generation Members unconsciously acquire certain "tacit knowledge" (Polanyi, 1975) - intangibles such as

6 - IESE Business School-University of Navarra 
family values and conceptions - simply by interacting with the family, the business and the predecessor (in some cases, the founder). This is in line with what Hasher and Zacks (1979, 1984) observed concerning automatic encoding.

Thus, learning or knowledge acquisition consists of three elements: subsidiary particulars, a focal target and, crucially, a person who links the two (Tsoukas and Vladimirou, 2001; in accordance with Polanyi, 1975). This idea is pretty much related and in fact reinforces CulturalHistorical Activity Theory (CHAT), which provides an orientation toward learning by stating that human action (in this case: knowledge acquisition) has a tripartite structure: Subject, Object and Mediating Artifact.

\section{Figure 1}

Cultural-Historical Activity Theory (CHAT)

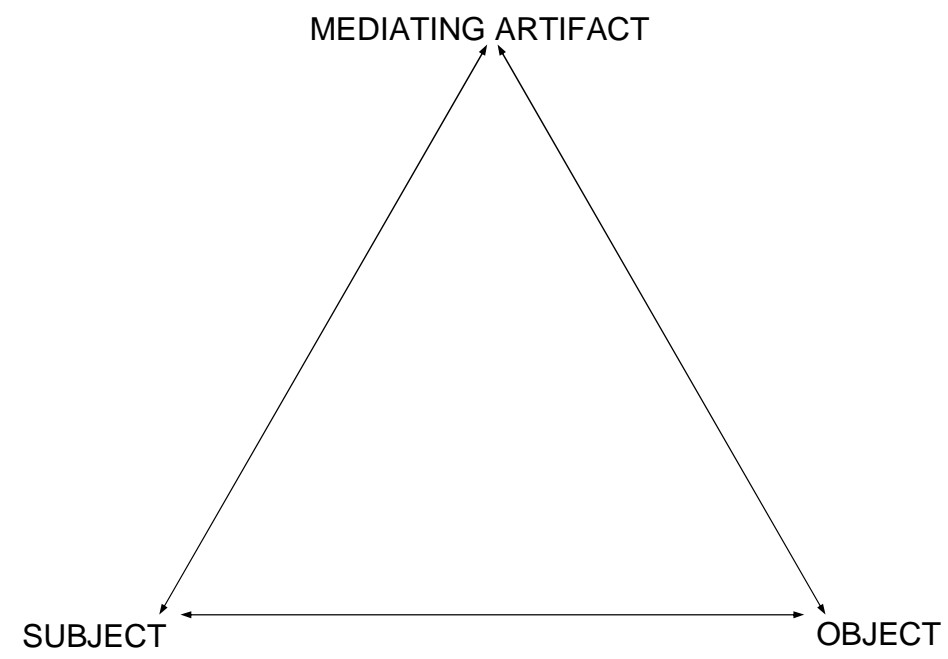

Source: University of Helsinki, "Cultural-Historical Activiy Theory," Center for Activity Theory and Developmental Work Research, http://www.edu.helsinki.fi/activity/pages/chatanddwr/chat/

CHAT was initially developed during 1920s and 1930s by Lev Vygotsky, based on the theses on Feuerbach (by Marx), which presented the agenda for overcoming the opposition between idealism and mechanistic materialism through the concept of activity. The key concept of the first-generation CHAT was mediation: artifact-mediated and object-oriented action. A person never reacts directly to the environment, but through the use or mediation of tools, cultural means, signs, etc. Vygotsky characterized the development of the intellect as an ongoing dialectic of instrumental and abstract processes, through which the mind took shape by means of the reactive and transformative relations in which people engage with the world (Keller and Dixon Keller, 1996).

Therefore, based on Tsoukas and Vladimirou's model and on Cultural-Historical Activity Theory - Vygotsky's model of mediated action - of how learning or knowledge acquisition (ACTION) takes place, we apply the same tripartite structure of knowledge acquisition, which tacitly implies a "transmission" to our main issue: knowledge transfer in family firms. We have consequently developed a Transmission Model of Knowledge in Family Businesses, which takes into account not only the three main elements in the learning/knowledge acquisition process, but also the most significant groups that interact in the family firm during knowledge transfer: 
Family, Enterprise, and Next Generation Members. Each of the components is treated as an independent, yet related and influential element, being:

1) Enterprise $=$ Object $/$ Focal Target.

2) Family $=$ Mediated Artifact/Subsidiary Particulars.

3) Next Generation $=$ Subject $/$ Person that integrates focal target and particulars.

The model relates The SUBJECT/Person, the OBJECT/Focal Target and the MEDIATED ARTIFACT/Subsidiary Particulars (unconscious) in the following way: First, the SUBJECT/Person, who is represented by the NEXT Generation Member(s) must learn/acquire knowledge (ACTION) about how to run the family firm, which is represented as the OBJECT/Focal Target. In order to do so, the SUBJECT/Person needs an artifact or tool that helps him carry out the human activity (Knowledge Acquisition). This mediating artifact is represented by the FAMILY. Thus, knowledge transfer (acquisition) takes place in and through a social context.

One of the central ideas in Polanyi's concept of knowledge is tradition. Tradition describes how knowledge is transferred precisely in social contexts. Tradition is a system of values outside of the individual. Indeed, tradition is a social system which takes up, stores and conveys the knowledge held by society - or the family (Sveiby, 1997). This kind of knowledge transfer is represented by the master-apprentice relationship (craftsmanship) which has been in use for centuries.

"To learn by example is to submit to authority. By watching the master and emulating his efforts in the presence of his example, the apprentice unconsciously picks up the rules of the art, including those which are not explicitly known to the master himself."

(Polanyi, 1975).

Thus, 'The individual lets the ... cultural patterns of the tradition form his own idiosyncrasies into an image of reality, irrespective of whether his tools are patterns of thought, patterns of action or social institutions. As time passes, some of the values are validated and transformed cognitively into beliefs about how things are. They are therefore no longer in need of being tested so they become a taken-for-granted tacit knowledge shared by the members of the group' (Sveiby, 1997, w/p). As a result, the FAMILY acts as a mediating artifact in conjunction with tradition (an intertwined tool embedded in the family context). Tools are created and transformed during the development of the activity itself and they carry with them a particular culture (historical remains from their development). Consequently, the use of tools is in itself an accumulation and transmission of social knowledge and tool use (tradition) influences the nature of external behavior and also individuals' mental functioning (Kaplelinin and Nardi, 1997).

The family therefore acts as a reference system which contains a well-defined structure of values, ideas, behaviors, norms and general knowledge, which is transmitted unconsciously to the individual (Next Generation Member) by means of traditions from the time he is born. The Next Generation capitalizes those traditions, acquiring the knowledge, integrating it, applying it and increasing it. Of course, the Next Generation's Level of Commitment to the Family Business will affect the knowledge assimilation process and patterns, being a determinant factor (variable) in effective and qualitative knowledge transfer. In fact, this transmission effort only makes complete sense when all three actors are fully aligned. Based on the work done by Fiol 
and Lyles (1985), alignment implies a potential to learn, unlearn or relearn based on past behaviors. The work of Chakravarthy (1982), Chandler (1962), Cyert and March (1963), Hambrick (1983), Miles and Snow (1978), and Miller and Friesen (1980) on firms and their strategies recognizes the widespread acceptance of this premise. Here, we are not applying the term only to firms, but also to the whole Family-Firm-Next Generation system. Consequently, if the three components do not show the same direction - potential to learn, unlearn and relearn, the final output may vary.

\section{Figura 2}

Knowledge Transfer Model in Family Firms (KTFF)

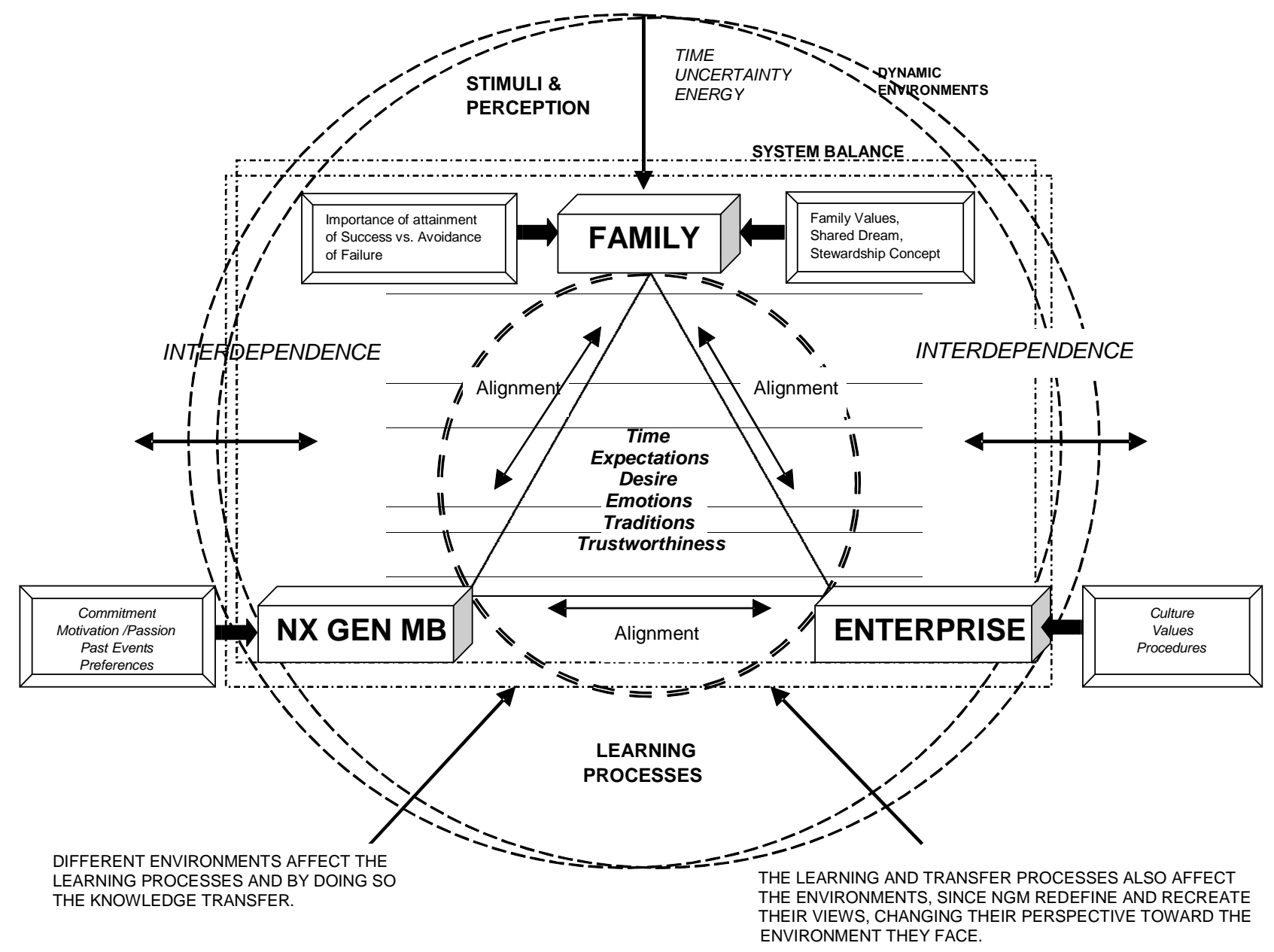

Source: Rosa Nelly Trevinyo-Rodriguez, "Knowledge Transfer Model in FF," presented at the EFMD $35^{\text {th }}$ Conference: Sustaining the Entrepreneurial Spirit Over Time, Sept. 2005, Barcelona, Spain.

In the previous figure, each square represents "A System Balance - depending on the environment faced", each Big Dashed Circle stands for "One different dynamic environment," while the small double-lined circle symbolizes the dynamistic-cause effect interrelationship among actors. 
As we can see, learning and adaptation occurs along several dimensions simultaneously (Herriot, Levinthal, and March, 2001). From a population ecology perspective and a strategic management view, the ultimate criterion of the system's performance is its long-term survival and growth. To achieve this, the system must find different balances depending on the environment it moves/coexists in. We must also take into account the fact that these environments are also dynamic, changing continuously and being affected by time, uncertainty, energy imposed, past events, etc. Furthermore, the system needs to find an alignment among its elements (actors) in order to adapt to the general ambience. However, this alignment is also cyclical and dynamic, preserved by a sustained strong cause-effect relationship among actors. System Adaptation, Alignment and Actors' Assimilation of knowledge (learning) regarding the environments, as well as the force of the interrelationship System Balance-Environment-Actors will determine the family firm's survival/death and fit/misfit in the community.

The successor (or candidates) - Next Generation Members - is embedded in the family system since he is born, and as the individual develops his personality, habits and beliefs, the family transmits him certain views and ideologies as well as memories and values that preserve certain behaviors, mental maps, norms and ideas. The same thing happens with the other members embedded in the family system, who experience this isomorphic adaptation to the point that cognitive systems, associations and memories are developed and shared among them. All of these systems, associations and memories are kept alive and passed from one generation to the next as family traditions. However, even when traditions are transmitted to us from the past, we apply our own interpretations to them, which have been developed within the context of our own immediate problems -environments- (Polanyi, 1983). Our perceptions and received stimuli from the environments we face affect our reinterpretation of traditions, and as a byproduct, impact our actions (behavior) and learning processes. The NGM consequently acts on the "environments"; what is received as perceptions and stimuli are returned as redefined, recreated and changing actions that modify the surroundings - i.e., a never-ending cyclic process through which continuous feedback is acquired and by which traditions are adapted and redefined, though not completely changed (except under special or extreme circumstances).

\section{Conclusion}

When evaluating succession processes one of the most important variables related to the procedure's quality-effectiveness is knowledge transfer. Nonetheless, as we pointed out before, knowledge transmission in family firms is/takes place differently from knowledge transmission in non-family firms, due to intangibles related to family value systems and traditions. Some of the most relevant variables and conditions that, according to our conceptual model, affect knowledge transmission in family firms are now synthesized below.

Regarding the variables, we identified two classes: 1) Those that are common to/affect the whole system (Essential Variables of the whole system), and 2) Those that are particularly focused on a specific actor (Family and Next Generation Variables). For practical reasons and to make it easy to remember, we grouped the common variables (class one) together and constructed the EDUCATE Standard (Education of Next Generation Members), while the specific variables (class two) are listed according to the actor they have an effect upon. 
CLASS ONE: ESSENTIAL VARIABLES OF THE WHOLE SYSTEM: EDUCATE Standard (Education of Next Generation Members).

Effective Time - Rewards, punishments, repetition, feedback

Desire - Shared dream, pride in being member of the family and enterprise

Uncertainty - Degree

Communication - Trustworthiness

Attitudes - Emotions - Previous beliefs, successes, failures

Traditions - Value systems - Unconscious stimuli

Expectations - Motivations

CLASS TWO: OTHER SPECIFIC VARIABLES AFFECTING KNOWLEDGE TRANSMISSION

\begin{tabular}{|c|c|}
\hline $\begin{array}{l}\text { FAMILY VARIABLES } \\
\text { (SOURCE of Knowledge) }\end{array}$ & $\begin{array}{l}\text { NEXT GENERATION VARIABLES } \\
\text { (Knowledge Acquirer/ Learner) }\end{array}$ \\
\hline $\begin{array}{l}>\text { Values, Expectations, Ideas } \\
>\quad \text { Stewardship Concept } \\
>\quad \text { Social Capital (how strong } \\
\text { relationships between NGM and } \\
\text { parents are?) } \\
>\quad \text { Availability of the source of knowledge } \\
>\quad \text { Desire to transfer knowledge } \\
>\quad \text { Trust }\end{array}$ & $\begin{array}{l}>\text { Commitment and Disposition } \\
>\text { Motivation } \\
>\text { Passion and Expectations } \\
>\text { Past Events } \\
>\text { Preferences } \\
>\text { Time dedicated to learning }\end{array}$ \\
\hline
\end{tabular}

Regarding the conditions required in order for effective knowledge transfer to take place across generations in the context of family firms, we detected that some desirable on-stage circumstances/settings were:

$\square$ The Next Generation Members' learning process must start at an early stage (childhood), since 'learning' is enhanced over time with such practices as repetition, rewards and punishments, feedback and practice.

$\square$ For effective learning to take place, commitment, expectations, values and perceptions have to be shared between the predecessor and the NGMs (explicit and implicit communication is needed).

$\square$ Learning processes must be "constructed" in such a way that they show challenging and solvable situations highly related to real life and to future work.

However, although learning/knowledge acquisition is a process intended to be helpful during critical periods, for instance, succession in family firms, learning does not always lead to intelligent behavior. Experience or wisdom cannot be completely told, and consequently the Next Generation has to "live" its own knowledge processes and apply its judgment and reasoning to the problem being faced, making its own mistakes and learning from them. The 
predecessors' task is to provide a context where NGMs can develop their potentialities in an orderly, not too costly and guided manner. But in the end, "Passing the torch involves doing on the part of the Next Generation”... Knowledge is personal; it is an ART.

\section{Further Research}

Since the overall KTFF model we have proposed here includes many different variables and/or constructs which are difficult not only to measure but also to examine jointly, we propose certain specific ideas in order to test the model "by parts," breaking it down into more manageable pieces of research.

In order to understand how to shape and/or transform the learning processes undertaken by NGMs in the course of their lives, we need first to map out these processes/relationships. To facilitate this task, we propose basing the mapping procedure on the proposed relationships (interactions) presented in the KTFF model. Thus, a research testing knowledge acquisition (learning) during different stages of the NGMs' lives - for instance, childhood, adolescence, early maturity and maturity - may be insightful, showing whether the interactions among the Family, the Enterprise and the NGMs are different or not at separate points in time. Basically, the idea is to dynamically map out how the KTFF model changes over time (along these different stages) in order to detect whether there are certain key points where learning patterns have changed. If so, the next question would be why these patterns have changed from one stage to another.

Another focus of research could be to assess the antecedents of constructs such as Next Generation Commitment and/or Trust (among others) and then see how these antecedents are related either to the Enterprise, to the Family (context), to NGMs' individual personality, or to a pair/all of the basic variables, as well as to the learning patterns that the NG Members exhibit over time (stages). Factor Analysis and Structural Equation Modeling could help a lot in order to group antecedents and to detect causal relationships.

It would be equally attractive to analyze the literature related to the "psychology of child development" and to observe how the learning processes that take place during childhood can be effectively fostered or inhibited - and if so, to what extent - by the contexts/conditions they grow up in (Family-Enterprise relationship), as well as by the use of such practices as repetition, rewards and punishments, feedback and practice.

Similarly, an attention-grabbing line of investigation would be to test how NGMs develop special skills for Family Businesses (tacit knowledge) in early stages of their lives, and to examine how early and until when (time) NGMs are more receptive to learning these abilities.

Finally, we also suggest testing how/which values overlap between predecessor and NGMs, and their relationship to the NGMs' Commitment to the business and to the Family. The latter may be useful for predicting and also for understanding various conflicts that arise not only during the succession phase, but also during the daily relationships between predecessors and NGMs.

Although they are recommended here, these future research ideas are not intended to be exhaustive; many more lines of investigation may be - and we expect they are opened/developed in order to contribute to our knowledge and understanding of processes in family businesses. 


\section{References}

Allen, M. and J. Stiff (1989), “Testing three models for the sleeper effect," Western J. Speech Comm., Vol., 53, pp. 411-426.

Argote, Linda, Sara Beckman, and Dennis Epple (1990), "The persistence and transfer of learning in industrial settings," Management Science, February, Vol. 36, No. 2. pp. 140-154.

Asian Productivity Organization (2001), "Knowledge Management: A Key Corporate Competitiveness," Report of the APO Top Management Forum.

Bahrick, H. P. (1984), "Semantic Memory content in permastore: Fifty years of memory for Spanish Learned in School,” J. Exp. Psychol: Gen. Vol. 13, pp. 1-29.

Banner, Mary and Michael L. Tushman (2002), "Process Management and Technological Innovation: A longitudinal study of the photography and paint industries," Administrative Science Quarterly, Vol. 47, pp. 676-706.

Bass, B.M., and J.A. Vaughn (1966), "Training in Industry: the Management of Learning," Belmont, CA: Wadsworth.

Bower, G.H. (1981), “Mood and Memory”, Am. Psychol., Vol. 36. pp. 129-148.

Carrillo, Francisco J. (2002), "Capital Systems: Implications for a Global Knowledge Agenda," Journal of Knowledge Management, Vol. 6, No. 4. October, pp. 379-399.

Cangelosi, Vincent and William Dill (1965), "Organizational Learning: Observations Toward a Theory,” Administrative Science Quarterly, Vol. 10, pp. 175-203.

Carlile, P.R. (2004), "Transferring, Translating and Transforming: An Integrative Framework for Managing Knowledge Across Boundaries,” Organization Science, Sept.-Oct., Vol. 15:5, pp. 555568.

Chakravarthy, B.S. (1982), "Adaptation: A promising metaphor for strategic management," Academy of Management Review, pp. 735-744.

Chandler, A. (1962), “Strategy and Structure,” Cambridge, MA: MIT Press.

Coleman, J. (1988), "Social capital in the creation of human capital," American Journal of Sociology, Vol. 94, pp. 95-120.

Cyert, R. and J. March (1963), “A Behavioral Theory of the Firm,” NJ, US: Prentice Hall.

Daft, R.L. and K. E. Weick (1984), "Toward a model of organizations as interpretation systems," Academy of Management Review, Vol. 9, pp. 284-295.

Damasio, A.R. (1994), “Descartes' error: Emotion, reason and human brain," NY: Grosset/Putnam.

Dixon, N.F. (1971), "Subliminal Perception: The Nature of a Controversy," London: McGrawHill.

Duncan, Robert and Andrew Weiss (1979), "Organizational learning: Implications for organizational design,” Research in Organizational Behavior, Volume 1, Ed. Barry M. Straw, USA: JAI Press, pp. 75-123. 
Erdelyi, M.H. (1984), “The recovery of unconscious (inaccessible) memories: Laboratory studies of hypermnesia," In Bower G.H. Psychology of Learning and Motivation, Vol. 18, New York: Academic, pp. 95-127.

Erdelyi, M.H. (1985), “Psychoanalysis: Freud's Cognitive Psychology,“ New York: Freeman.

Fiol, C. Marlene and Marjorie A. Lyles (1985), "Organizational learning," Academy of Management Review, Vol. 10, No. 4, pp. 803-813.

Fowler, C.A., G. Wolford, R. Slade, and L. Tassinary (1981), "Lexical access with and without awareness," J. Exp. Psychol: Gen. Vol. 110, pp. 341-362.

Freire, P. (1970), "The adult literacy process as cultural action for freedom," Harvard Educational Review, Vol. 40, pp. 205-225.

Freire, P. (1970), "Cultural Action and Conscientization," Harvard Educational Review, Vol. 40, pp. 452-477.

Freire, P. (1973), “Education for Critical Consciousness,” New York: Seabury Press.

Frost, Peter, Larry F. Moore, Meryl Res Louis, et al. (1985), “Organizational Culture," USA: SAGE Publications.

Gadanho S.C. and L. Custódio (2002), "Asynchronous Learning by Emotions and Cognition," Proceedings of the Seventh International Conference on Simulation of Adaptive Behavior on: From animals to animats, August 05-09, 2002, Portugal.

Goldstein, Irwin L. and J. Kevin Ford (2002), “Training in Organizations,” Canada: Wadsworth (Thomson Learning).

Grandori, A. and B. Kogut (2002), "Dialogue in Organization and Knowledge," Organization Science, May-June, Vol. 13:3., pp. 224-231.

Granovetter, M. (1985), "Economic Action and Social Structure: The Problem of Embeddedness," The American Journal of Sociology, Nov., Vol. 91:3, pp. 481-510.

Grusky, O. (1960), “Administrative Succession in Formal Organizations," Social Forces, Dec., Vol. 39:2, pp. 105-115.

Hall, Douglas T. and Cynthia V. Fukami, (1979), "Organizational Design and Adult Learning," Research in Organizational Behavior, Volume 1, Ed. Barry M. Straw, USA: JAI Press, pp. 125167.

Handler, W. (1990), "Succession in family firms. A mutual role adjustment between entrepreneur and next-generation family members," Entrepreneurship Theory and Practice, Vol. 15, pp. 37-51.

Handler, W. (1992), "The succession experience of the next generation," Family Business Review, Vol. 5:3, pp. 283-307.

Hambrick, D.C. (1983), "Some tests of the effectiveness and functional attributes of Miles and Snow's strategic types,” Academy of Management Journal, Vol 26, pp. 5-26.

Hannan, Michael T. and John Freeman (1984), "Structural inertia and organizational change," American Sociological Review, Apr., Vol. 49, No. 2, pp. 149-164.

14 - IESE Business School-University of Navarra 
Hasher, L. and R.T. Zacks (1979), “Automatic and effortful processes in memory," J. Exp. Psychol: Gen., Vol. 108, pp. 356-388.

Hasher, L. and R.T. Zacks (1984), "Automatic processing of fundamental information: The case of frequency of occurrence," Am. Psychol., Vol. 39, pp. 1372-1388.

Hedberg, B. (1981), "How Organizations Learn and Unlearn," in P. Nystrom and W. Starbucks (eds.), Handbook of Organizational Design, Vol. 1, Oxford: Oxford University Press, pp. 3-27.

Hedberg, B., P. Nystrom, and W.H. Starbuck (1976), "Camping on seesaws: Prescriptions for a self designing organization,” Administrative Science Quarterly, Vol. 21, pp. 41-65.

Herriott, Scott, Daniel Levinthal, and James G. March (2001), "Learning from Experience in Organizations,” American Economic Review, Vol. 75, pp. 298-302.

Hovland, C., A. Lumsdaine, and F. Sheffield (1949), "Experiments in Mass Communication," Princeton, NJ: Princeton University Press.

Johnson, M.K. and L. Hasher (1987), "Human Learning and Memory," Ann. Rev. Psychol., Vol. 38, pp. 631-668.

Kaplelinin V. and B.A. Nardi (1997), “Activity Theory: Basic Concepts and Applications,” CHI 97 Electronic Publications: Tutorials. http:/www.acm.org/sigchi/chi97/proceedings/ tutorial/bn.htm

Kaptelinin, V., K. Kuutti, and L. Bannon (1995), "Activity Theory: Basic Concepts and Applications," In Blumenthal et al. (eds.), Human-Computer Interaction, Lecture Notes in Computer Science, Spring.

Keller, C. and J. Dixon Keller (1996), "Cognition and Tool Use: The Blacksmith at Work," Cambridge: Cambridge University Press.

Kihlstrom, J.F. (1984), “Conscious, subconscious, unconscious: A cognitive perspective," In Bower G.H. Psychology of Learning and Motivation, Vol. 18, New York: Academic, pp. 149211.

Lawrence, P. R. and D. Dyer (1983), “Renewing American Industry,” NY, US: The Free Press.

LeDoux J.E. (1996), “The Emotional Brain,” New York: Simon \& Schuster.

Levitt, Barbara and James G. March (1988), "Organizational Learning," Annual Review of Sociology, Vol. 14, pp. 319-340.

Lewin, A.Y. and C. Wolf (1975), "The Theory of Organizational Slack: A Critical Review," Proceedings, Twentieth International Meeting of the Institute of Management Sciences, North Holland.

Lieberman, A. (1972), "Organizational Learning Environments: Effects and Perceptions of Learning Constraints,” Doctoral Dissertation, Stanford University, 238 pages.

Lounammaa, Pertti and James G. March (1987), “Adaptive coordination of a learning team,” Management Science, Jan., Vol. 33, No.1, pp. 107-123. 
Malinen, Pasi and Irma Vento-Vierikko (2002), "Like Father Like Son? Transfer of Entrepreneurship in Small Family Businesses in the Finnish Context -Some critical Elements," Paper presented at a Family Business Network Conference.

Marcel, A. (1983), "Conscious and unconscious perception: Experiments on visual masking and word recognition,” Cognit. Psychol., Vol. 15, pp. 197-237.

March, J. and J.P. Olsen (1975), "The Uncertainty of the past: Organizational Learning under ambiguity," European Journal of Political Research, Vol. 3, pp. 147-171.

Marx, Karl (1886), “Theses On Feuerbach,” As an Appendix to Engels' Ludwig Feuerbach and the End of Classical German Philosophy, From Marx/Engels Selected Works, Volume One, pp. 13-15. Progress Publishers, Moscow, USSR, 1969, http://www.marxists.org/archive/marx/ works/1845/theses/theses.htm

McCauley, C., C.M. Parmelee, R.D. Sperber, and T.H. Carr (1980), "Early extraction of meaning from pictures and its relation to conscious identification," J. Exp. Psychol. Hum. Percept, Perform., Vol. 6, pp. 265-276.

Miles, R.E. and C.C. Snow (1978), “Organizational strategy, structure and process," NY, US: McGraw-Hill.

Miller, D. and P.H. Friesen (1980), "Momentum and revolution in organization adaptation," Academy of Management Journal, Vol. 23, pp. 591-614.

Perry, D.K. (1996), "Theory and Research in Mass Communication: Contexts and Consequences," NJ: Lawrence Erlbaum Associates.

Pfeffer, Jeffrey and Robert I. Sutton (2000), “The Knowing-Doing Gap,” USA: Harvard Business School Press.

Philips, Jack J. and Toni Krucky Hodges (1999), "Measuring Learning and Performance," USA: American Society for Training \& Development.

Piaget, J. (1968), “Genetic Epistomology,” Columbia University Press, Structuralist.

Piaget, J. (1983), “Piaget's theory,” In P. Mussen (ed.), Handbook of Child Psychology, 4th edition, Vol. 1, New York: Wiley.

Picard, R.W. (1997), “Affective Computing,” Cambridge, MA: MIT Press.

Polanyi, M. (1962), “Personal Knowledge,” Chicago, IL: University of Chicago Press.

Polanyi, M. (1975), “Personal Knowledge,” In Polanyi, M and H. Prosch (editors), Meaning, Chicago, IL: University of Chicago Press, pp. 22-45.

Polanyi, M. (1983), "Personal knowledge: towards a post-critical philosophy," London: Routledge \& Kegan Paul.

Probst, Gilbert, Steffen Raub, and Kai Romhardt (2000), "Managing Knowledge: Building Blocks for Success," UK: Wiley.

Rempel, J.K., J.G. Holmes, and M.P. Zanna (1985), “Trust in close relationships," Journal of Personality and Social Psychology, Vol. 49:1, pp. 95-112. 
Rogers, E.M. and F.F. Shoemaker (1971), "Communication of Innovations: A Cross-Cultural Approach," NY, US: The Free Press.

Salasoo, A., R.A. Shiffrin, and T.C. Feustel (1985), "Building permanent memory codes: Codification and repetition effects in word identification,” J. Exp. Psychol: Gen., Vol. 114, pp. 50-77.

Sharma, Pramodita and P. Gregory Irving (2005), "Four bases of Family Business Successor Commitment: Antecedents and Consequences," Entrepreneurship Theory and Practice, February.

Sparrow, John (1998), "Knowledge in Organizations: Access to Thinking at Work," UK: SAGE Publications.

Starbuck, W.H., A. Greeve, and B. Hedberg (1978), "Responding to crisi," Journal of Business Administration, Vol. 9:2, pp. 112-137.

Stinchcombe, A. (1965), "Social Structure and Organizations," In James G. March (editor), Handbook of Organizations, Chicago: Rand McNally, pp. 153-193.

Sveiby, Karl Eric (1997), "Capital Intelectual: La nueva riqueza de las empresas: Cómo medir y gestionar los activos intangibles para crear valor,” España: Gestión 2000.

Sveiby, K.E. (1997), “Tacit Knowledge,” http://www.sveiby.com/articles/Polanyi.html

Szulanski, G., R. Cappetta, and R.J. Jensen (2004), "When and How Trustworthiness Matters: Knowledge Transfer and the Moderating Effect of Causal Ambiguity," Organizational Science, Sept.-Oct., Vol. 15:5, pp. 600-613.

Tsoukas, H. and E. Vladimirou (2001), "What is organizational knowledge?," Journal of Management Studies, November, Vol. 38:7, pp. 973-993.

Underwood, B.J. (1983), “Attributes of Memory,” IL: Scott Foresman.

University of Helsinki, "Cultural-Historical Activity Theory," Center for Activity Theory and Developmental Work Research, http://www.edu.helsinki.fi/activity/pages/chatanddwr/chat/

Van der Bent, J., J. Paauwe, and R. Williams (1999), “Organizational Learning: an exploration of organizational memory and its role in organizational change processes," Journal of Organizational Change Management, Vol. 12:5, pp. 377-404.

Varamäki, Elina, Timo Pihkala and Vesa Routamaa (2003), "Knowledge Transfer in Small Family Businesses," Paper presented during the 2003 FBN Conference.

Von Krogh, Georg and Johan Roos (1996), "Managing Knowledge: Perspectives in cooperation and competition,” UK: SAGE Publications.

Wathne, K., J. Roos, and G. von Krogh (1996), "Towards a theory of knowledge transfer in a cooperative context," in von Krogh, G. and J. Roos (eds.), "Managing knowledge: Perspectives on cooperation and competition," London, UK: Sage, pp. 55-81.

Weick, Karl Erik (1979), “The Social Psychology of Organizing,” USA: McGraw Hill, Inc.

Weick, Karl Erik (1979), "Cognitive Processes in Organizations," Research in Organizational Behavior, Volume 1, Ed. Barry M. Straw, USA: JAI Press, pp. 41-74. 
Wick, Calhoun W. and Lu Stanton León (1993), “The Learning Edge,” USA: McGraw Hill, Inc.

Wickens, D.D. and S. Clark (1968), "Osgood dimensions as an encoding class in short-term memory,” Journal of Exp. Psychol., Vol. 78, pp. 580-584.

Zucker, Lynne (1986),"Production of Trust: Institutional sources of economic structure, 1840 to 1920," Research in Organizational Behavior, Vol. 8, eds. Barry M. Straw and L.L. Cummings, USA: JAI, pp. 53-111. 